\title{
ANALISIS DAMPAK PEMEKARAN PROVINSI KALIMANTAN UTARA TERHADAP KESEJAHTERAAN MASYARAKAT DI KABUPATEN BULUNGAN TAHUN 2016-2018
}

\author{
Riezky Padillah Safitri \\ Mahasiswa Ilmu Pemerintahan, Ilmu Sosial Dan Ilmu Politik \\ Universitas Muhammadiyah Yogyakarta \\ Ladilah02@gmail.com \\ Ane Permatasari \\ Dosen Ilmu Pemerintahan, Fakultas Ilmu Sosial Dan Ilmu Politik \\ Universitas Muhammadiyah Yogykarta \\ anepermatasariyk@gmail.com
}

\begin{abstract}
Abstrak
Penelitian ini berusaha menjawab permasalahan daerah pemekaran dari segi percepatan pelayanan, pengelolaan potensi daerah, percepatan pertumbuhan ekonomi, pertumbuhan demokrasi, keamanan/ ketertiban, Hubungan pemerintah pusat dan daeran, dan IPM.Penelitian ini menggunakan metode deskripsif kualitatif dengan teknik pengumpulan data dokumentasi, kuesioner, wawancara, dan studi kepustakaan. Unit analisis data pemerintah Kab Bulungan dan Masyarakat Kab Bulungan. Berdasarkan analisis yang telah dilakukan, hasil dari penelitian ini Pemekaran Provinsi (Kalimantan Timur) menjadi Provinsi (Kalimantan Utara) membawa dampak positif terhadap kesejahteraan masyarakat ini dilihat dari hasil penelitian yang menunjukan bahwa hasil nilai Indeks setelah pemekaran sebesar 4,04 dan dapat dikategorikan Baik kerena Intervalnya diantara $(3,7-4,5)$. Hasil yang Baik ini juga tidak terlepas dari upaya serius yang dilakukan pemerintah dalam meningkatkan kesejahteraan masyarakat diantaranya peningkatan pelayanan publik terhadap masyarakat. Upaya yang telah di lakukan pemerintah juga membawa hasil yang positif dengan meningkatnya IPM Kabupaten Bulungan di setiap tahun nya. IPM Kab Bulungan tahun 2018 telah meningkat sebesar 71,23 dibandingkan dengan tahun 2017 70,74 dengan laju pertumbuhan IPM sebesar 0,7 persen.
\end{abstract}

\section{Kata Kunci : Otonomi Daerah, Pemekaran Wilayah, Kesejahteraan Hidup, IPM}

\section{Pendahuluan}

Indonesia adalah Negara Kesatuan, dibagi atas daerah-daerah provinsi dan daerah provinsi dibagi atas kabupaten/kota yang mempunyai pemerintah daerah (Roekminiati: 2014). Di keluarkanya "Undang - Undang Nomor 22 Tahun 1999 kemudian di revisi menjadi Undang - Undang Nomor 32 tahun 2004 tentang otonomi daerah yang mengakibatkan perubahan pada paradigma pemerintahan yang sebelumnya tersentralisasi menjadi terdesentralisasi dengan memberikan kesempatan kepada daerah untuk menyelenggarakan otonomi daerah". Otonomi baru atau pemekaran daerah ini memungkinkan daerah untuk mengelola sumber daya nasional sesuai dengan "Undang- 
undang 23 Tahun 2014 tentang pemerintah daerah, bahwa daerah mempunyai wewenang untuk mengelola dan memelihara sumber daya nasional yang dimiliki sesuai dengan aturan perundang - undangan".

Sejak diberlakukannya desentralisasi, pemerintah pusat tidak lagi menguasai kebijakan daerah. Pemerintah pusat hanya berperan dalam konteks otonomi adalah melakukan mengawasi, memantau, mengawasi, dan mengevaluasi pelaksanaan otonomi daerah. Oleh sebab itu, di perlukan kombinasi yang efektif antara visi yang jelas serta ke pemimpinan yang kuat dari pemerintah pusat, dengan keleluasaan berprakarsa dan berkreasi dari pemerintah daerah (Haris, 2005).

Sejalan dengan berlakukan desentralisasi di Indonesia, menimbulkan berbagai macam reaksi dari daerah-daerah. Dalam "Undang-Undang Nomor 20 Tahun 2012 tentang pembentukan provinsi Kalimantan Utara Khususnya di Kabupaten Bulungan, Kota Tarakan, Kabupaten Nunukan, Kabupaten Malinau dan Kabupaten Tana Tidung dipandang perlu meningkatkan penyelenggaraan pemerintahan, pembangunan dan pelayanan publik guna mempercepat terwujudnya kesejahteraan masyarakat". Memperhatikan kondisi geografis yang berbatasan langsung dengan Negara tetangga (Malaysia) baik darat maupun laut perlu dibentuknya Provinsi Kalimantan Utara.

Pembentukan Provinsi Kalimantan Utara ini terjadi akibat ketidakterjangkauan pemerintah dalam menjalankan fungsi pelayanan yang maksimal, akibat luasnya wilayah Provinsi Induk (Kalimantan Timur) yang memiliki luas wilayah daratan 127.267,52 km2 dan luas pengelolaan laut $25.656 \mathrm{~km} 2$. Provinsi Kalimantan Utara terpisah dari Kalimantan Timur karena wilayah Kalimantan Utara ini berbatasan langsung dengan negara tetangga Malaysia, yaitu Serawak dan Sabah. Untuk mengatasi ancaman kehilangan wilayah, salah satu hal yang sangat merugikan indonesia adalah kekalahan indonesia pada sengketa internasional Den Haag (Belanda) terkait pulau Sipadan dan Ligitan dengan Malaysia. Kekalahan Indonesia pada sangketa Pulau Sipadan dan Pulau Ligitan saat itu bukan karena fakta sejarah namun akibat terabainya pengelolaan lingkungan di kawasan itu. Kabupaten Bulungan dipilih sebagai wilayah induk (Kalimantan Utara) karena berdasarkan sejarah, semua daerah di wilayah utara (Kalimantan) itu dulunya masuk dalam wilayah Kesultanan Bulungan, sebelum menyatakan kesediaan bergabung dengan Pemerintahan RI tahun 1949 (https://humas.kaltaraprov.go.id/).

Pada tanggal 25 oktober 2012, Provinsi Kalimantan Utara secara resmi terbentuk setelah ditandatanganinya "Undang - Undang Nomor 20 Tahun 2012 tentang 
24 | Safitri, Permatasari. Analisis Dampak Pemekaran...

pembentukan Provinsi Kalimantan Utara pada tanggal 16 november 2012 oleh Presiden RI Susilo Bambang Yudhoyono". RUU pembentukan Provinsi Kalimantan Utara sebelumnya telah disetujui oleh rapat paripurna pada 25 Oktober 2012 untuk menjadikan Undang - Undang (UU). Sejak terbit "UU No.20 Tahun 2012 maka resmi terbentuk Provinsi Kalimantan Utara sebagai Provinsi ke 34 di Indonesia". Pada tanggal 22 April 2013 Pejabat Gubernur Kalimantan Utara yaitu Irianto Lambrie dilantik oleh Mentri Dalam Negeri Gamawan Fauzi di Jakarta (http://disperindagkop.kaltaraprov.go.id)

Kesejahteraan masyarakat adalah buah dari pelayanan publik yang dilakukan pemerintah. Kesejahteraan dapat dilihat dari beberapa indikator. Badan Pusat Statistik Indonesia dalam mengukur pembangunan manusia untuk mengetahui tingkat kesejahteraan masyarakat (https://www.bps.go.id). Menurut (Roekminiati: 2014) "pelaksanaan pembangunan seutuhnya senantiasa menempatkan manusia sebagai titik sentral Dalam hal ini, pembangunan di tunjukan untuk memajukan kesejahteraan umum, mencerdaskan kehidupan bangsa dan meningkatkan partisipasi rakyat dalam semua proses dan kegiatan pembangunan dengan demikian maka pembangunan manusia menjadi tujuan utama pembangunan melalui peningkatan kemampuan sumber daya manusia agar mampu menjadi subyek pembangunan". Peningkatan pembangunan manusia untuk meningkatkan kesejahteraan masyarakat dapat dilihat dari beberapa indikator, salah satunya adalah indikator Indeks Pembangunan Manusia yang di lihat melalui tiga aspek, yaitu aspek pendidikan, aspek kesehatan, dan aspek pengeluaran perkapita menyebutkan bagaimana penduduk dapat mengakses pembangunan melalui harapan hidup saat lahir, melek huruf, rata-rata lama sekolah, dan pengeluaran per kapita (https://kaltara.bps.go.id).

IPM Kabupaten Bulungan tahun 2017, 70.74\% meningkat tahun 2016 sebesar $69.88 \%$ dan laju pertumbuhan IPM sebesar 1.23\% dan IPM Bulungan Tahun 201871.23 (https://bulungankab.bps.go.id). Pelaksanaan pemekaran wilayah telah berjalan beberapa tahun dan diharapkan dapat memperbaiki kualitas hidup rakyat sehingga tercapai kesejahteraan masyarakat yang lebih baik. Bukan hanya tugas pemerintah daerah, tetapi juga ini menjadi tugas masyarakat setempat dalam berpartisipasi untuk mendukung kebijakan pemerintah daerah dalam hal pembangunan, yang pada akhirnya akan berdampak pada kesejahteraan masyarakat.

Berdasarkan uraian di atas, penulis tertarik untuk meneliti lebih jauh dampak dari otonomi daerah yang sudah berjalan dan upaya pemerintah dalam meningkatkan Indeks Pertumbuhan Masyarakat di Kabupaten Bulungan. Dengan judul penelitian "Analisi 
Dampak Pemekaran Provinsi Kalimantan Utara Terhadap Kesejahteraan Masyarakat Di Kabupaten Bulungan".

\section{Tinjauan Pustaka}

\section{A. Otonomi Daerah}

Istilah Otonomi Daerah berasal dari Bahasa Yunani yaitu autos = sendiri dan nomos = Undang-undang, yang berarti perundangan sendiri (Izelf Watgeving). "Otonomi Daerah dalam Kamus Besar Bahasa Indonesia (KBBI) berarti hak, wewenang, dan kewajiban daerah untuk mengatur dan mengurus rumah tangganya sendiri sesuai dengan peraturan perundang-undangan yang berlaku". Pengertian ini ternyata tidak berbeda dari "Undang-undang Nomer 23 tahun 2014 Otonomi Daerah adalah hak, wewenang, dan kewajiban daerah otonom untuk mengatur dan mengurus sendiri Urusan Pemerintahan dan kepentingan masyarakat setempat dalam sistem Negara Kesatuan Republik Indonesia".

"Tujuan otonomi daerah berdasarkan pasal 2 ayat (3) UU No. 32 Tahun 2004 adalah meningkatkan kesejahteraan masyarakat pelayanan umum dan daya saing daerah". Prinsip otonomi daerah yang dianut oleh "UU No. 32 Tahun 2004 tentang pemerintah daerah adalah otonomi daerah yang luas, nyata dan bertanggung jawab, memberikan kewenangan yang lebih banyak kepada daerah Kabupaten/Kota didasarkan atas asas desentralisasi".

Menurut "UU No 23 Tahun 2014 Penyelenggaraan otonomi daerah menggunakan 3 asas" yaitu :

1) Desentralisasi

a) Desentralisasi adalah penyerahan wewenang pemerintahan oleh Pemerintah Pusat kepada daerah otonom untuk mengatur dan mengurus urusan pemerintahan dalam kerangka Negara Kesatuan Republik Indonesia (NKRI) (Kumorotomo, 2008).Konsep desentralisasi terdiri atas desentralisasi politik (political decentralization), desentralisasi administrasi (administrative decentralization), dan desentralisasi fiskal (fiscal decentralization) (Sidik, 2002) .

Menurut Said (2008), terdapat empat segi positif otonomi daerah:

1) Demokratisasi,

2) Membantu meningkatkan kualitas dan efisiensi pemerintahan,

3) Mendorong stabilitas dan kesatuan nasional, Memajukan pembangunan daerah. 
26 | Safitri, Permatasari. Analisis Dampak Pemekaran...

a. Pemekaran Wilayah

Menurut "PP Nomor 78 Tahun 2007, pemekaran wilayah adalah pemecahan provinsi atau kabupaten/kota menjadi dua daerah atau lebih". "Undangundangan Nomer 32 Tahun 2004 tentang pemerintah daerah, materi pemekaran wilayah tercantum pada pasal 4 ayat (3) dan (4)", tetapi istilah yang digunakan adalah pemekaran daerah artinya pengembangan dari suatu daerah otonom menjadi dua atau lebih daerah otonom. Pemekaran daerah adalah pemecahan atau pemisahan diri suatu daerah dengan wilayah induknya sebagai daerah otonomi baru untuk dapat berdiri sendiri dan menjadi daerah yang mandiri dimana syarat dan ketentuan pembentukan daerah diatur dalam peraturan pemerintah.

Menurut "(Hendrata: 2018) Pemekaran daerah harus mengutamakan kesejahteraan rakyat. Alasan-alasan pemekaran wilayah adalah" :

1) Mendekatkan Pelayanan kepada masyarakat,

2) Alasan historis, pemekaran suatu daerah dilakukan karena alasan sejarah, bahwa daerah hasil pemekaran memiliki historis tertentu,

3) Kultural atau Budaya (etnis), karena menggangap adanya perbedaan budaya antar daerah yang bersangkutan dengan daerah induknya,

4) Ekonomi, pemekaran wilayah di harapkan untuk mempercepat pembangunan,

5) Anggaran, pemekaran daerah dilakukan untuk mendapatkan anggaran dari pemerintah. Sebagaimana di ketahui bahwa daerah yang di mekarkan mendapatkan anggaran dari induknya selama 3 tahun dan mendaptkan dana dari pemerintah pusat (DAU dan DAK),

6) Keadilan.

Menurut "Peraturan Pemerintah No.129 Tahun 2000, tentang persyaratan pembentukan dan kriteria pemekaran, penghapusan dan penggabungan daerah, pada pasal 2 menyebutkan pemekaran daerah/ wilayah bertujuan untuk meningkatkan kesejahteraan masyarakat" melalui:

1) "Percepatan pelayanan kepada masyarakat;"

2) "Percepatan pertumbuhan kehidupan demokrasi;"

3) "Percepatan pertumbuhan pembangunan ekonomi daerah;"

4) "Percepatan pengelolaan potensi daerah;"

5) "Peningkatan keamanan dan ketertiban;"

6) "Peningkatan hubungan yang serasi antara pusat dan daerah".

Menurut Gulo dalam Hendrata (2019) Tujuan yang relevan dengan pemekaran daerah adalah untuk : 
1) Meningkatkan pelayanan dan kesejahteraan kepada masyarakat,

2) Memperkokoh basis ekonomi masyarakat,

3) Mengatur perimbangan keuangan daerah dan pusat,

4) Membuka peluang dan lapangan pekerjaan,

5) Memberikan peluang daerah untuk mendapatkan investor secara langsung.

Menurut" (Syah N : 2018) bicara mengenai manfaat dari pemekaran wilayah adalah adalah memeberikan masukan pada pemerintah daerah terkait dengan kondisi rill di lapangan sehingga mempermudah atau memperpendek jangkauan pelayanan yang baik kepada masyarakat pada kondisi geografis yang sulit di jangkau oleh pemerintah daerah baik melalui transportasi udara, darat dan laut. Terwujudnya keinginan masyarakat dalam mempercepat peningkatan tingkat kesejahteraan dalam segala aspek kehidupan baik pendidikan,kesehatan, sosial budaya dan politik serta pembangunan infrastruktur yang memadai".

b. Kesejahteraan Hidup

Menurut Norizon dan luca dalam Sari, M.E.P, Pratiwi, D.A (2018) juga menyatakan bahwa kesejahteraan hidup objektif di ukur berdasarkan faktorfaktor yang bisa dilihat seperti pendapatan dan tabungan sedangkan kesejahteraan hidup subjektif adalah berpedoman pengalaman secara psikologi. Kesejahteraan hidup dapat terbagi menjadi dua aspek utama yaitu keseajhteraan ekonomi dan kesejahteraan sosial (Nadir, 2015).

a. Kesejahteraan Sosial

Kesejahteraan sosial meliputi aspek perumahan, hubungan sosial, administrasi, keamanan, keterlibatan sosial, kebudayaan, keseahtan, lingkungan dan keluarga. "Menurut Undang-undang Republik Indonesia Nomor 11 tahun 2009, kesejahteraan Sosial adalah kondisi terpenuhinya kebutuhan material, spiritual, dan sosial warga negara agar dapat hidup layak dan mampu mengembangkan diri, sehingga dapat melaksanakan fungsi sosialnya, dan penyelenggaraan kesejahteraan sosial adalah upaya yang terarah, terpadu, dan berkelanjutan yang dilakukan Pemerintah, pemerintah daerah, dan masyarakat dalam bentuk pelayanan sosial guna memenuhi kebutuhan dasar setiap warga negara, yang meliputi rehabilitasi sosial, jaminan sosial, pemberdayaan sosial, dan perlindungan sosial. Dimana dalam penyelanggaraannya dilakukan atas dasar kesetiakawanan, keadilan, kemanfaatan, keterpaduan, kemitraan, keterbukaan, akuntabilitas, partisipasi, profesionalitas dan keberlanjutan". 
Dalam upaya mewujudkan kesejahteraan sosial tersebut, diperlukan pembangunan kesejahteraan sosial. "Menurut Suharto (2005), pembangunan kesejahteraan sosial usaha yang terencana dan terarah yang meliputi berbagai bentuk intervensi sosial dan pelayanan sosial untuk memenuhi kebutuhan manusia, mencegah dan mengatasi masalah sosial, serta memperkuat institusiinstitusi sosial. Atau dalam pengertian kemajuan yang dicapai oleh masyarakat dalam mewujudkan kesejahteraan sosial".

b. Kesejahteraan Ekonomi

"Kesejahteraan ekonomi meliputi aspek trasnportasi, komunikasi, pendapatan, dan karir. Kesejahteraan hidup suatu masyarakat membei fokus kepada sumber keuangan dan penggunaan terhadap sumber tersebut bagi mencapai tujuan yang didinginkan Laily dan jaria dalam Sari (2018). Menurut Laily dan Jaria dalam Sari (2018) Perubahan ekonomi suatu masyarakat bisa diukur melalui pendapatan perkapita, daya beli, peningkatan konsumsi, jumlah modal, penyediaan kemudahan transportasi, biaya, jumlah tabungan dan perbelanjaan serta perdagangan, Karir".

Terdapat berbagai perkembangan pengukuran tingkat kesejahteraan dari sisi fisik, seperti Human Development Index (Indeks Pembangunan Manusia), Physical Quality Life Index (Indeks Mutu Hidup), Basic Needs (Kebutuhan Dasar), dan GNP/Kapita (Pendapatan Perkapita). Ukuran kesejahteraan ekonomi inipun bisa dilihat dari dua sisi, yaitu konsumsi dan produksi (skala usaha). Dari sisi konsumsi maka kesejahteraan bisa diukur dengan cara menghitung seberapa besar pengeluaran yang dilakukan seseorang atau sebuah keluarga untuk kebutuhan sandang, pangan, papan, serta kebutuhan lainnya dalam waktu atau periode tertentu.

Menurut Bps-Bappenas-Undp (2004) Kesejahteraan masyarakat dapat di lihat dari beberapa indikator.salah satu indikator yang di pakai adalah indeks pembangunan manusia yang mengukur capaian umum suatu daerah dalam dimensi utama pembangunan manusia. "IPM adalah alat yang digunakan untuk mengukur seberapa tinggi tingkat pembangunan manusia yang mencakup empat variabel, yaitu (1) harapanhidup, (2) angka melek huruf, (3) rata-rata lama sekolah dan (4) penghasilan riil kapita yang disesuaikan".

c. Indeks Pembangunan Manusia

Menurut UNDP (1990:1) Pembangunan manusia adalah suatu proses untuk memperbesar pilihan-pilihan bagi manusia. Dari definisi ini dapat di tarik kesimpulan bahwa fokus pembangunan suatu negara adalha penduduk karena penduduk adalah kekayaan suatu negara. Indeks Pembangunan Manusia (IPM) merupakan alat Ukur yang dapat di gunakan dalam upaya dan kinerja, 
pembangunan manusia di suatu wilayah UNDP (1990). Pada dasarnya IPM mengukur tigas dimensi pokok pembangunan manusia yang dinilai mencerminkan status kemampuan dari penduduk, yaitu:

1) Umur panjang dan sehat yang mengukur peluang hidup,

2) Berpengetahuan dan berketerampilan,

Akses terhadap sumber daya yang di butuhkan untuk mencapai standar hidup layak.

\section{Metode Penelitian}

Jenis penelitian ini adalah penelitian kualitatif yang bersifat deskriptif, dimana metode "metode penelitian kualitatif adalah penelitian yang diawali dengan mengumpulkan informasi untuk dirumuskan menjadi suatu generalisasi yang rasional (Sugiyono, 2014: 9)". Dari sifatnya, penelitian ini bersifat deskriptif analisis, dimana dalam penelitian ini peneliti akan menggambarkan hasil dari analisis pemekaran Provinsi Kalimantan Utara terhadap kesejahteraan masyarakat di Kabupaten Bulungan. Desain yang digunakan dalam penelitian ini adalah Time Series Design. Time Series Design merupakan desain penelitian yang bermaksud untuk mengetahui kestabilan dan kejelasan suatu keadaan yang tidak menentu (Sugiyono, 2014).

Data yang di gunakan dalam metode deskriptif, yang di butuhkan adalah data primer dan sekunder. Data primer adalah data yang di peroleh langsung dari subyek penelitian dengan menggunakan alat pengukuran atau pengambilan data secara langsung menggunakan kuisioner (Sugiyono, 2014). "Data sekunder adalah data yang di peroleh lewat pihak lain dan tidak langsung dari subyek penelitian (Azwar, 2005:91)". Baik berupa literatur pendukung lainya berupa buku, media masa, internet, arsip, dokumen dan lain sebagainya yang berkaitan dengan dampak pemekaran terhadap kesejahteraan masyarakat Kabupaten Bulungan.

Penelitian ini menggunakan "populasi dan sampel dimana menurut Menurut Sugiyono (2017:80), Populasi adalah wilayah generalisasi yang terdiri atas; obyek/subyek yang mempunyai kualitas dan karakteristik tertentu yang ditetapkan oleh peneliti untuk dipelajari dan kemudian ditarik kesimpulannya. Menurut Sugiyono (2017:81), Sampel adalah bagian dari jumlah dan karakteristik yang dimiliki oleh populasi tersebut. Bila populasi besar, dan peneliti tidak mungkin mempelajari semua yang ada pada populasi, misalnya karena keterbatasan dana, tenaga dan waktu, maka peneliti dapat menggunakan sampel yang diambil dari populasi itu". Populasi dalam penelitian ini yaitu masyarakat yang berada di Kabupaten Bulungan dengan jumlah sample 100 responden dari 
30 | Safitri, Permatasari. Analisis Dampak Pemekaran...

5 kecamatan. Dalam menetukan sample, penulis menggunakan metode pengambilan cluster sampling (area sampling) dengan daerah populasi yang telah di tentukan.

Teknik pengumpulan data dalam penelitian ini adalah observasi Dalam penelitian ini, peneliti melakukan observasi atau pengamatan secara langsung terhadap objek yang akan diteliti, dimana objek tersebut adalah masyarakat Kabupaten Bulungan. Kemudian Peneliti menggunakan kuesioner dalam melakukan penelitian ini. Dimana kuesioner ini berupa pernyataan yang dijawab oleh responden. Pernyataan dalam kuesioner ini mencangkup indikator dari pemekaran wilayah dan indikator IPM. Bentuk kuesioner berupa pernyataan dan responden memberikan jawabannya dengan memberi tanda centang pada pilihan jawaban yang tersedia. Dalam penelitian ini menggunakan wawancara yaitu pengumpulan data yang dilakukan dengan cara tanya jawab secara lisan dengan informasi guna memperoleh keterangan secara langsung (Widoyoko, 2012:25). Dengan metode interview penelitian harus memikirkan pelaksanaannya untuk mendapatkan jawaban narasumber dengan bertatap muka (Arikunto, 1997:231). Studi kepustakaan yang digunakan oleh peneliti adalah dengan mengumpulkan data dan informasi dari buku, media masa, internet, arsip, dokumen dan lain sebagainya yang berkaitan dengan dampak pemekaran terhadap kesejahteraan masyarakat Kabupaten Bulungan.

\section{Pembahasan}

Peraturan Pemerintah "No.129 Tahun 2000, tentang persyaratan pembentukan dan kriteria pemekaran, penghapusan dan penggabungan daerah, pada pasal 2 menyebutkan pemekaran daerah/ wilayah bertujuan untuk meningkatkan kesejahteraan masyarakat melalui Percepatan pelayanan kepada masyarakat,Percepatan pertumbuhan kehidupan demokrasi,Percepatan pertumbuhan pembangunan ekonomi daerah,Percepatan pengelolaan potensi daerah,Peningkatan keamanan dan ketertiban,Peningkatan hubungan yang serasi antara pusat dan daerah". Dalam mengukur kesejahteraan masyarakat Bps-bappenas-undp menggunakan indeks pembangunan manusia yang mencakup tiga aspek yaitu pendidikan,kesehatan dan daya beli/pengeluaran per kapita.

Pemekaran wilayah Provinsi Kalimantan Timur menjadi Provinsi Kalimantan Utara ini membawa dampak yang baik. Hal ini dapat dilihat dari beberapa aspek penelitian Menurut PP No. 129 Tahun 2000 : 
1. Kemudahan mendapatkan dan menjangkau pelayanan publik setelah pemekaran.

Berdasarkan Hasil Kuisoner kemudahan dalam mendapatkan dan menjangkau pelayanan publik sesudah pemekaran yang menjawab "sangat baik 16 orang dengan persentase $16 \%$, menjawab baik 59 orang dengan persentase $59 \%$, menjawab cukup 24 orang dengan persentase 24\%, menjawab kurang 1 orang dengan persentase $1 \%$ dan menjawab sangat kurang tidak ada. Dari jumlah responden 100 dengan persentase 100\%".

Responden yang menjawab sangat baik dan baik merasakan bahwa setelah pemekaran hal yang sangat di rasakan adalah kemudahan dalam menjangkau pelayanan publik karena sudah dekat dan tidak jauh seperti wilayah induk yang dulu, mudah dalam melakukan urusan-urusan penting karena pelayanan yang sangat baik. kemudian infrastruktur jalan yang sangat baik baik darat maupun udara. Jika dulu tidak ada pesawat, sekarang dengan perbaikan bandara maka akses udara telah lancar.

Responden yang menjawab kurang hanya terdapat 1 orang, dan responden tersebut merasakan bahwa setelah pemekaran, kemudahan dalam mendapatkan dan menjangkau pelayanan publik sama saja sama seperti dulu. Dikarenakan area wilayahnya belum terjangkau oleh pemerintah dalam pembangunan insfrastruktur seperti perbaikan jalan.

kemudahan dalam mendapatkan menjangkau pelayanan publik sesuai dengan hasil kuisioner sudah baik ini dibuktikan dengan upaya pemerintah dalam meningkatkan pelayanan publik di Provinsi Kalimantan Utara seperti yang di ikuti oleh peneliti dalam infopublik.id sebagai berikut :

"Dalam rangka memberikan akses kemudahan kepada masyarakat dalam hal pelayanan. Pemerintah Kabupaten Bulungan (Pemkab) akan membentuk Mall Pelayanan Publik (MPP). Pembentukan MPP di prakarsai oleh Dinas Penanaman Modal dan Pelayanan Terpadu Satu Pintu (DPMPTSP) sebagai leading sektornya."

Pemerintah Provinsi Kalimantan Utara tidak hanya membangun Mall pelayanan publik tetapi juga mendirikan aplikasi yang berguna untuk percepatan pelayanan kepada masyarakat seperti yang dikutip dalam prokal.co sebagai berikut :

"Dinas Pekerjaan Umum dan Penataan Ruang (PUPR) Bulungan meluncurkan aplikasi Lintang dan Siabang yang berlangsung di Ruang Serbaguna Lantai II Kantor Bupati Bulungan. Aplikasi Lintang berisi layanan informasi tata ruang sedangkan siabang berupa sistem informasi penyelenggaraan bangunan gedung. Menurut Bupati Bulungan H.Sudjati SH "apalikasi Lintang atau layanan 
32 | Safitri, Permatasari. Analisis Dampak Pemekaran...

informasi tata ruang, dapat membantu Aparatur Sipil Negara di Dinas PUPR mendapatkan informasi terkini secara digital terkait data informasi penataan ruang secara optimal serta mempercepat proses perizinan berusaha. Kemudian melalui aplikasi siabang atau sistem informasi penyelenggaraan bangunan gedung, dapat mempermudah serta mempercepat pelayanan dalam pemberian informasi terkait pelayanan penyelenggaraan bangunan gedung yang di perlukan oleh masyarakat, dunia usaha ataupun instansi pemerintah melalui petugas loket layanan Dinas PUPR Bulungan"

Berdasarkan keterangan di atas aplikasi siabang menggabungkan sistem informasi, indeks kepuasaan masyarakat dan layanan pengaduan, sehingga sejalan dengan upaya pemerintah untuk meningkatkan standar pelayana publik, menjamin keandalan teknis bangunan gedung serta meningkatkan iklim investasi dan reformasi birokrasi.

Selain hasil wawancara dari hasil kuisioner tersebut juga dibuktikan dengan hasil nilai indeks dampak pemekaran Provinsi Kalimantan Utara terhadap kesejahteraan masyarakat di Kabupaten Bulungan, seperti tercantum dari perhitungan dibawah ini:

$$
\begin{aligned}
\text { Indeks }= & (16 \times 5)+(59 \times 4)+(24 \times 3)+(1 \times 2)+(0 \times 1) / 100 \\
& =390 / 100 \\
& =3,9
\end{aligned}
$$

Indeks kemudahan mendapatkan dan menjangkau pelayanan publik setelah pemekaran dapat dilihat sebesar 3,9. Jadi dapat disimpulkan bila hal tersebut diukur dalam intervalnya maka dapat dikategorikan Baik yaitu intervalnya $(3,7-$ $4,5)$. Dari hasil interval dapat dilihat bahwa masyarakat merasakan kemudahan dalam menjangkau pelayanan publik dikarenakan wilayah induk yang sudah berada di Kalimantan Utara dan pembangunan infrastruktur jalan yang sangat baik.

2. Kehidupan demokrasi setelah pemekaran di daerah ini sangat baik dan membawa kesejahteraan bagi masyarakat.

Berdasarkan hasil hasil kuisioner kehidupan demokrasi sesudah pemekaran di daerah ini sangat baik dan membawa kesejahteraan bagi masyarakat yang menjawab "sangat baik 21 orang dengan persentase $21 \%$, menjawab baik 56 orang dengan persentase $56 \%$, menjawab cukup 19 orang dengan persentase $19 \%$, menjawab kurang 2 orang dengan persentase $2 \%$ dan terakhir menjawab sangat kurang 2 orang dengan persentase $2 \%$. dari responden berjumlah 100 orang dengan persentase $100 \% "$.

Responden yang memilih jawaban sangat baik, baik dan cukup, merasakan bahwa kehidupan demokrasi sesudah pemekaran sangat baik dan membawa 
kesejahteraan masyarakat terlihat dari, masyarakat merasakan bahwa pada saat pesta demokrasi setiap masyarakat selalu mendaptkan hak suara baik yang muda maupun yang tua sehingga tidak ada satupun masyarakat yang merasa di rugikan karena tidak mendapatkan hak suara.

Dari beberapa responden yang menjawab kehidupan demokrasi sangat kurang karena ada beberapa yang tidak mengerti terhadap kehidupan berdemokrasi sehingga mereka merasakan bahwa kehidupan demokrasi sangat biasa-biasa saja.

Berdasarkan keterangan di atas dapat juga di buktikan dengan penghargaan yang di dapatkan oleh Kalimantan Utara seperti yang dikutip dari tribunkaltim.co sebagai berikut:

"Kaltara menerima penghargaan dari Kementrian Politik Hukum dan Hak Asasi Manusia sebagai Provinsi Yang Capaian IDI 2018 Kategori "Baik" hasil ini membuktikan bahwa Kaltara memiliki iklim demokrasi yang kondusif di likungan yang heterogen. IDI di ukur berdasarkan 3 aspek, 11 variabel dan 28 indikator demokrasi"

IDI kalimantan Utara dari 3 aspek yang di ukur tersebut, kebebasan sipil kaltara memperoleh poin 97,36, aspek hak-hak sipil 75.80 poin dan aspek kelembagaan demokrasi mencapai 68,95 poin. Menurut BPS Kaltara dibandingkan dengan IDI tahun 2017, pada 2018 mengalami kenaikan meskipun hanya naik 0,01 dari sebelumnya tahun 2017 81,06 dan 2016 sebesar 76.98.

Selain hasil wawancara dari hasil kuisioner tersebut juga dibuktikan dengan hasil nilai indeks dampak pemekaran Provinsi Kalimantan Utara terhadap kesejahteraan masyarakat di Kabupaten Bulungan, seperti tercantum dari perhitungan dibawah ini:

$$
\begin{aligned}
\text { Indeks } & =(21 \times 5)+(56 \times 4)+(19 \times 3)+(2 \times 2)+(2 \times 1) / 100 \\
& =392 / 100 \\
& =3,92
\end{aligned}
$$

Indeks kehidupan demokrasi sangat baik dan membawa kesejahteraan bagi masyarakat setelah pemekaran dapat dilihat sebesar 3,92. Jadi dapat disimpulkan bila hal tersebut diukur dalam intervalnya maka dapat dikategorikan Baik yaitu intervalnya $(3,7-4,5)$. Dari hasil interval dapat dilihat bahwa masyarakat merasakan kehidupan demokrasi setelah pemekaran baik karena saat pesta demokrasi setiap masyarakat selalu mendapatkan hak suara baik yang muda maupun tua sehingga tidak ada masyarakat yang merasa dirugikan karena tidak mendapatkan hak suaranya.

3. Pembangunan ekonomi berupa sarana dan prasarana setelah pemekaran. 
34 | Safitri, Permatasari. Analisis Dampak Pemekaran...

Berdasarkan hasil kuisioner pembangunan ekonomi berupa saranan dan prasarana sesudah pemekaran yang menjawab "sangat baik 31 orang dengan persentase $31 \%$, menjawab baik 53 orang dengan persentase $53 \%$, menjawab cukup 14 orang dengan persentase 14\%, menjawab kurang 2 orang dengan persentase $2 \%$ dan menjawab sangat kurang tidak ada. Dari 100 responden dengan persentase $100 \% "$.

responden yang memilih jawaban sangat baik, baik dan cukup, merasakan pembangunan ekonomi berupa saranan dan prasarana sesudah pemekaran sangat baik karena dapat dilihat dari infrastruktur jalan yang sudah sangat baik kemudian dilihat dari infrastruktur udara sudah ada dengan itu kegiatan ekonomi sudah bisa berjalan dengan lancar.

Responden yang menjawab Kurang dan Sangat Kurang merasakan bahwa memang pembangunan ekonomi berupa prasarana sudah baik tetapi akses jalan ini sangat cepat sekali rusak akibat dilewati truk-truk yang bermuatan banyak dan tidak terdapatnya alternatif jalan untuk truk yang membawa muatan berat.

Berdasarkan keterangan diatas, dapat dilihat bahwa pembangunan ekonomi berupa saranan dan prasarana sesudah pemekaran sangat baik. Hal yang sangat dirasakan oleh semua masyarakat adalah infrastruktur jalan yang membaik sehingga kegiatan ekonomi berjalan dengan lancar. Hal ini sesuai dengan hasil wawancara dengan Kepala Bagian Ekonomi Kabupaten Bulungan sebagai berikut:

"...menurut saya bahwa dengan adanya Provinsi Kalimantan utara ini membawa dampak yang baik terhadap Kabupaten Bulungan karena fokus pembangunan pasti ada di Kabupaten Bulungan. kalau dulu sebelum menjadi Kalimantan Utara jalanan saja banyak yang rusak parah namun setelah menjadi Kalimantan Utara infrastruktur jalan sudah membaik"

(hasil wawancara dengan Kabag. Perekonomian Kabupaten Bulungan)

Selain hasil wawancara dari hasil kuisioner tersebut juga dibuktikan dengan hasil nilai indeks dampak pemekaran Provinsi Kalimantan Utara terhadap kesejahteraan masyarakat di Kabupaten Bulungan, seperti tercantum dari perhitungan dibawah ini:

Indeks $\quad=(31 \times 5)+(53 \times 4)+(14 \times 3)+(2 \times 2)+(0 \times 1) / 100$

$=413 / 100$

$=4,13$

Indeks pembangunan ekonomi berupa sarana dan prasarana sesudah pemekaran dapat dilihat sebesar 3,13. Jadi dapat disimpulkan bila hal tersebut diukur dalam intervalnya maka dapat dikategorikan Baik yaitu intervalnya (3,7- 
4,5). Dari hasil interval dapat dilihat bahwa masyarakat merasakan infrastruktur jalan yang sudah baik kemudian infrastruktur udara yang sudah ada sehinggah kegiatan ekonomi sudah bisa berjalan dengan lancar.

4. Pengelolaan potensi daerah setelah pemekaran.

Berdasarkan hasil kuisioner Pengelolaan potensi daerah sesudah pemekaran menjawab "sangat baik 25 orang dengan persentase 25\%, menjawab baik 57 orang dengan persentase 57\%, menjawab cukup 17 orang dengan persentase $17 \%$, menjawab kurang 1 orang dengan persentase $1 \%$ dan menjawab kurang tidak ada . Dari 100 responden dengan persentase 100\%".

Responden yang memilih jawaban sangat baik, baik dan cukup merasa pengelolaan potensi daerah sesudah pemekaran baik karena efeknya ada di pembangunan daerah yang meningkat.

Responden yang menjawab kurang dan sangat kurang merasakan pengelolaan potensi daerah sesudah pemekaran sebenarnya sudah baik tetapi karena efek dari pengelolaan potensi daerah ini hasilnya tidak bisa dinikmati secara merata.

Berdasarkan hasil diatas, dapat dilihat bahwa ada 1 orang yang merasa pengelolaan potensi daerah sesudah pemekaran kurang baik karena tidak dapat merasakan hasil pembangunan yang dilakukan pemerintah dari uang hasil pengelolaan potensi daerah. Kembali lagi karena ada beberapa orang yang tidak perduli terhadap apa yang telah di lakukan pemerintah. Dan sisahnya merasakan pengelolaan potensi daerah sangat baik. Pengelolaan potensi daerah menurut Kepala Dinas ESDM Provinsi Kalimantan Utara sebagai berikut

"...potensi sumber daya alam Kabupaten Bulungan ada dua jenis yaitu sumber daya dapat terbarukan contohnya seperti pembangkitan listrik, sungai, matahari, angin cangkang sawit. Tidak terbarukan yaitu tambang emas, batu bara, golongan C, minyak dan gas. Setiap kecamatan memilik sumber daya alam seperti batu bara, emas dan gas"

(hasil wawancara dengan Kepala Dinas ESDM Provinsi Kalimantan Utara).

"...alasan utama pemanfaatan pengelolaan potensi daerah adalah untuk kemakmuran dan kesejahteraan rakyat dari hasil pajak, royalty tambang digunakan untuk pembangunan daerah"

(hasil wawancara dengan Kepala Dinas ESDM Provinsi Kalimantan Utara).

Selain hasil wawancara dari hasil kuisioner tersebut juga dibuktikan dengan hasil nilai indeks dampak pemekaran Provinsi Kalimantan Utara terhadap kesejahteraan masyarakat di Kabupaten Bulungan, seperti tercantum dari perhitungan dibawah ini:

Indeks $=(25 \times 5)+(57 \times 4)+(17 \times 3)+(1 \times 2)+(0 \times 1) / 100$ 
36 | Safitri, Permatasari. Analisis Dampak Pemekaran...

$$
\begin{aligned}
& =406 / 100 \\
& =4,06
\end{aligned}
$$

Indeks pengelolaan potensi daerah sesudah pemekaran dapat dilihat sebesar 4,06. Jadi dapat disimpulkan bila hal tersebut diukur dalam intervalnya maka dapat dikategorikan Baik yaitu intervalnya $(3,7-4,5)$. Dari hasil interval dapat dilihat efek dari pengelolaan potensi daerah adalah pembangunan daerah yang meningkat.

5. Keamanan daerah setelah pemekaran.

Berdasarkan Hasil Kuisioner Tingkat keamanan daerah yang menjawab "sangat baik 23 orang dengan persentase 23\%, menjawab baik 51 orang dengan persentase $51 \%$, menjawab cukup 24 orang dengan persentase $24 \%$, menjawab kurang 2 orang dengan persentase $2 \%$ dan menjawab sangat kurang tidak ada. Dari responden 100 orang dengan persentase $100 \% "$.

Responden yang menjawab sangat baik dan baik merasakan bahwa tingkat keamanan daerah setelah pemekaran baik karena tingkat ekonomi masyarakatnya menengah keatas, kesadaran masyarakat untuk hidup rukun tinggi dan banyak tempat penyaluran hobi yang membawa energi positif dan terdapat lapangan pekerjaan yang banyak sehingga tidak ada tindakan kriminal.

Responden yang menjawab kurang dan sangat kurang merasakan bahwa tingkat keamanan daerah setelah pemekaran sebenarnya baik tetapi dengan berkembangnya wilayah Kalimantan Utara khususnya Kabupaten Bulungan, menarik banyak masyarakat dari wilayah lain yang masuk kedalam wilayah Kabupaten Bulungan dan konflik yang sering terjadi disebabkan oleh masyarakat pendatang. Tetapi konflik itu frekuensinya masih sangat kecil terjadi.

Hal ini terbukti dengan upaya pemerintah mewujudkan keamanan dan ketertiban luncurkan SINCAN atau Aksi Tindak Cepat Pelajar Nakal di kutip dari Koran Kaltara "Sekkab Bulungan SINCAN merupakan aksi atau gerakan yang bersifat pembinaan serta memberikan pemahaman dan penyadaran kepada pelajar akan tindakan-tindakan kriminal dan perbuatan menyimpang yang mungkin dilakukan pelajar.Selain mengapresiasi langkah pencegahan itu, Sekkab Bulungan juga mengharapkan aksi ini bisa turut mewujudkan dan menciptakan keamanan, ketertiban umum, serta menciptakan kondisi tertib, melalui kepedulian terhadap pelajar dan pendidikan di wilayah Kabupaten Bulungan."

Selain hasil wawancara dari hasil kuisioner tersebut juga dibuktikan dengan hasil nilai indeks dampak pemekaran Provinsi Kalimantan Utara 
terhadap kesejahteraan masyarakat di Kabupaten Bulungan, seperti tercantum dari perhitungan dibawah ini:

Indeks

$$
\begin{aligned}
& =(23 \times 5)+(51 \times 4)+(24 \times 3)+(2 \times 2)+(0 \times 1) / 100 \\
& =395 / 100 \\
& =3,95
\end{aligned}
$$

Indeks keamnan daerah sesudah pemekaran dapat dilihat sebesar 3,95. Jadi dapat disimpulkan bila hal tersebut diukur dalam intervalnya maka dapat dikategorikan Baik yaitu intervalnya $(3,7-4,5)$. Dari hasil interval dapat dilihat bahwa tingkat keamanan daerah rendah tetapi tiingkat ekonomi masyarakat menengah keatas dan terdapat lapangan pekerjaan yang banyak sehingga tidak ada tindakan kriminal.

6. Hubungan serasi antar pusat (Pemerintah Provinsi) dan Daerah (Pemerintah Kabupaten/Kota) setelah pemekaran.

Berdasarkan Hasil Kuisioner Hubungan serasi antara pusat dan daerah setelah adanya pemekaran yang menjawab "sangat baik 24 orang dengan persentase $24 \%$, menjawab baik 60 orang dengan persentase $60 \%$, menjawab cukup 16 orang dengan persentase $16 \%$, menjawab kurang dan sangat kurang tidak ada. Dari 100 responden dengan persentase $100 \% "$.

Responden yang menjawab sangat baik, baik dan cukup merasakan bahwa hubungan serasi antara pusat dan daerah setelah pemekaran sangat baik ini dikarena wilayah induk yang sudah berada diwilayah Kabupaten Bulungan sehingga pembangunan diwilayah Bulungan dan sekitarnya merata.

Selain hasil wawancara dari hasil kuisioner tersebut juga dibuktikan dengan hasil nilai indeks dampak pemekaran Provinsi Kalimantan Utara terhadap kesejahteraan masyarakat di Kabupaten Bulungan, seperti tercantum dari perhitungan dibawah ini:

$$
\begin{aligned}
\text { Indeks }= & (24 \times 5)+(60 \times 4)+(16 \times 3)+(0 \times 2)+(0 \times 1) / 100 \\
= & 408 / 100 \\
= & 4,08
\end{aligned}
$$

Indeks hubungan serasi antara pusat (pemerintah provinsi) dan daerah (pemerintah kab/kota) setelah pemekaran dapat dilihat sebesar 4,08. Jadi dapat disimpulkan bila hal tersebut diukur dalam intervalnya maka dapat dikategorikan Baik yaitu intervalnya $(3,7-4,5)$. Dari hasil interval dapat dilihat bahwa masyarakat merasakan hubungan pusat dan daerah baik dikarena wilayah induk yang sudah berada diwilayah Kabupaten Bulungan sehingga pembangunan diwilayah Bulungan dan sekitarnya merata.

Pemekaran wilayah Provinsi Kalimantan Timur menjadi Provinsi Kalimantan Utara ini membawa dampak yang baik. Hal ini dapat dilihat dari 
38 | Safitri, Permatasari. Analisis Dampak Pemekaran...

beberapa aspek penelitian Menurut Bps-bappenas-undp menggunakan indeks pembangunan manusia sebagai berikut :

1. Aspek kesehatan setelah pemekaran.

Berdasarkan Hasil kuisioner Tingkat kesehatan setelah pemekaran yang menjawab sangat baik 24 orang dengan persentase 24\%, menjawab baik 58 orang dengan persentase $58 \%$, menjawab cukup 18 orang dengan persentase $18 \%$, menjawab kurang dan sangat kurang tidak ada. Dari 100 responden dengan persentase $100 \%$.

Responden yang menjawab sangat baik, baik dan cukup, merasakan bahwa tingkat kesehatan setalah pemekaran sangat baik karena fasilitas yang memadai, kemudian banyaknya bantuan kesehatan gratis untuk semua lapisan masyarakat dari pemerintah.

Berdasarkan hasil wawancara diatas, dibuktikan dengan adanya upaya pemerintah Provinsi Kalimantan Utara dalam meningkatkan pelayanan kesehatan di kutip dari Kla.id Gubernur Kalimantan Utara menyampaikan Upaya pemerintah untuk menjamin kesehatan masyarakatnya terutama untuk masyarakat miskin dengan program menjemput pasien dengan ambulans gratis lanjut ungkap Gubernur kalimantan Utara.

"saya sudah instruksikan kepada semua jajaran kesehatan, agar memberikan pelayanan yang maksimal kepada warga miskin. Kita juga memiliki ambulans air yang siap melayani warga secara gratis"

(Dikutip Dari Kla.id)

Gubernur Kalimantan Utara juga mengungkapkan Program lainnya, ada dokter terbang. Melalui program ini, Pemerintah Provinsi menyediakan dokter spesialis dan beberapa tenaga media lainnya, untuk memberikan pelayanan kesehatan dengan sistem 'jemput bola' ke wilayah-wilayah yang sulit terjangkau layanan kesehatan.

Tidak hanya itu upaya pemerintah Kalimantan Utara untuk meningkatkan kesejahteraan masyarakat "dikutip dari BPJS-Kesehatan.go.id dengan memberikan jaminan kesehatan bagi seluruh masyarakatnya juga direalisasikan dengan adanya penandatangan Komitmen UHC oleh Gubernur Provinsi Kalimantan Utara, Irianto Lambrie, melakukan penandatanganan komitmen tentang Universal Health Coverage (UHC), Terhitung 1 April 2018, 14.624 masyarakat Provinsi Kalimantan Utara yang tersebar di seluruh kota dan kabupaten telah didaftarkan menjadi peserta JKN-KIS yang iuran setiap bulannya dibayarkan oleh Pemerintah Provinsi dengan menggunakan anggaran APBD. Sampai dengan komitmen UHC tersebut ditandatangani, jumlah 
masyarakat di Provinsi Kalimantan Utara yang terdaftar sebagai peserta JKNKIS sejumlah 532.011 jiwa atau sekitar $86,14 \%$ dari total jumlah penduduk 651.519 jiwa".

Selain hasil wawancara dari hasil kuisioner tersebut juga dibuktikan dengan hasil nilai indeks dampak pemekaran Provinsi Kalimantan Utara terhadap kesejahteraan masyarakat di Kabupaten Bulungan, seperti tercantum dari perhitungan dibawah ini:

$$
\begin{aligned}
\text { Indeks }= & (24 \times 5)+(58 \times 4)+(18 \times 3)+(0 \times 2)+(0 \times 1) / 100 \\
= & 406 / 100 \\
= & 4,06
\end{aligned}
$$

Indeks Aspek kesehatan setelah pemekaran dapat dilihat sebesar 3,71. Jadi dapat disimpulkan bila hal tersebut diukur dalam intervalnya maka dapat dikategorikan Baik yaitu intervalnya $(3,7-4,5)$. Dari hasil interval dapat dilihat bahwa masyarakat merasakan tingkat kesehatan setalah pemekaran Baik karena fasilitas yang memadai, kemudian banyaknya bantuan kesehatan gratis untuk semua lapisan masyarakat dari pemerintah.

2. Tingkat pelayanan pendidikan setelah pemekaran.

Berdasarkan hasil Tingkat pelayanan pendidikan setelah pemekaran menjawab "sangat baik 31 orang dengan persentase 31\%, menjawab baik 62 orang dengan persentase $62 \%$, menjwab cukup 7 orang dengan persentase $7 \%$ dan menjawab kurang dan sangat kurang tidak ada. Dari 100 responden dengan persentase $100 \% "$.

Responden yang menjawab sangat baik dan baik merasakan bahwa tingkat pendidikan setelah pemekaran sangat baik karena menyediakan beasiswa bagi seluruh lapisan masyarakat di kalimantan utara kemudian fasilitas dan tenaga pengajar yang memadai.

Berdasarkan hasil wawancara tersebut, di buktikan dengan upaya pemerintah dalam meningkatkan pelayanan kepada masyarakat melalui bantuan beasiswa kaltara cerdas seperti yang Dikutip dari Kaltarabisnis.co Upaya Pemerintah Prov.Kaltara untuk meningkatkan pendidikan adalah dengan memberikan bantuan beasiswa merata baik di tingkat provinsi maupun kabupaten di wilayah Provinsi Kalimantan Utara untuk jenjang SMA/SMK Negeri/Swasta, program Diploma, S-1/D-IV, S-2, S-3, Kedokteran dan Pendidikan Profesi.

Selain hasil wawancara dari hasil kuisioner tersebut juga dibuktikan dengan hasil nilai indeks dampak pemekaran Provinsi Kalimantan Utara 
terhadap kesejahteraan masyarakat di Kabupaten Bulungan, seperti tercantum dari perhitungan dibawah ini:

$$
\begin{aligned}
\text { Indeks }= & (31 \times 5)+(62 \times 4)+(7 \times 3)+(0 \times 2)+(0 \times 1) / 100 \\
= & 424 / 100 \\
= & 4,24
\end{aligned}
$$

Indeks tingkat pelayanan pendidikan setelah pemekaran dapat dilihat sebesar 4,24. Jadi dapat disimpulkan bila hal tersebut diukur dalam intervalnya maka dapat dikategorikan Baik yaitu intervalnya $(3,7-4,5)$. Dari hasil interval dapat dilihat bahwa masyarakat merasa Baik karena Pemerintah menyediakan beasiswa bagi seluruh lapisan masyarakat di kalimantan utara kemudian fasilitas dan tenaga pengajar yang memadai.

3. Daya beli/pengeluaran per kapita setelah pemekaran.

Berdasarkan hasil Daya beli/pengeluaran perkapita setelah pemekaran yang menjawab "sangat baik 27 orang dengan persentase $27 \%$, menjawab baik 53 orang dengan persentase 53\%, menjawab cukup 18 orang dengan persentase $18 \%$, menjawab kurang 2 orang dengan persentase $2 \%$, menjawab sangat kurang tidak ada. Dari 100 responden dengan persentase $100 \% "$.

Responden yang menjawab sangat baik dan baik merasakan bahwa tingkat perekonomian setelah menjadi Kaltara semakin membaik sehingga mampu untuk memenuhi segala kebutuhan hidup.

Responden yang menjawab kurang hanya 2 orang karena merasa tidak mampu memenuhi kebutuhan hidup karena tingkat perekonomian yang masih di bawah rata-rata.

Selain hasil wawancara dari hasil kuisioner tersebut juga dibuktikan dengan hasil nilai indeks dampak pemekaran Provinsi Kalimantan Utara terhadap kesejahteraan masyarakat di Kabupaten Bulungan, seperti tercantum dari perhitungan dibawah ini:

$$
\begin{aligned}
\text { Indeks }= & (27 \times 5)+(53 \times 4)+(18 \times 3)+(2 \times 2)+(0 \times 1) / 100 \\
= & 405 / 100 \\
= & 4,05
\end{aligned}
$$

Indeks daya beli/pengeluaran per kapita sebelum pemekaran dapat dilihat sebesar 4,05. Jadi dapat disimpulkan bila hal tersebut diukur dalam intervalnya maka dapat dikategorikan Baik yaitu intervalnya $(3,7-4,5)$. Dari hasil interval dapat dilihat bahwa masyarakat merasa tingkat perekonomian setelah menjadi Kaltara semakin membaik sehingga mampu untuk memenuhi segala kebutuhan hidup. 
Pada penelitian ini ingin membuktikan adanya dampak provinsi kalimantan utara terhadap kesejahteraan masyarakat di Kabupaten Bulungan (Wilayah Induk) dilihat dari Indeks Setelah Pemekaran dibawah ini :

Tabel 4.1 Rerata Indeks Setelah Pemekaran

\begin{tabular}{|c|c|c|}
\hline No & Pertanyaan & $\begin{array}{c}\text { Indeks } \\
\text { Pertanyaan }\end{array}$ \\
\hline 1 & $\begin{array}{l}\text { Kemudahan mendapatkan dan menjangkau } \\
\text { pelayanan publik setelah pemekaran }\end{array}$ & 3,9 \\
\hline 2 & $\begin{array}{l}\text { Kehidupan demokrasi setelah pemekaran di daerah } \\
\text { ini sangat baik dan membawa kesejahteraan bagi } \\
\text { masyarakat. }\end{array}$ & 3,92 \\
\hline 3 & $\begin{array}{l}\text { Pembangunan ekonomi berupa sarana dan } \\
\text { prasarana setelah pemekaran. }\end{array}$ & 4,13 \\
\hline 4 & Pengelolaan potensi daerah setelah pemekaran. & 4,08 \\
\hline 5 & Keamanan daerah setelah pemekaran. & 3,95 \\
\hline 6 & $\begin{array}{l}\text { Hubungan serasi antar pusat (Pemerintah Provinsi) } \\
\text { dan daerah (Pemerintah Kabupaten/Kota) setelah } \\
\text { pemekaran. }\end{array}$ & 4,08 \\
\hline 7 & Aspek Kesehatan setelah pemekaran. & 4,06 \\
\hline 8 & Tingkat pelayanan pendidikan setelah pemekaran. & 4,24 \\
\hline 9 & $\begin{array}{l}\text { Daya beli/pengeluaran per kapita setelah } \\
\text { pemekaran. }\end{array}$ & 4,05 \\
\hline & Indeks Rerata & 4,04 \\
\hline
\end{tabular}

Sumber : Kuisioner

Rerata Indeks Sebelum Pemekaran :

$=3,9+3,92+4,13+4,08+3,95+4,08+4,06+4,24+4,05$

$=36,41 / 9$

$=4,04$

Rumus Interval :

$=\frac{5-1}{5}$

$=0,8$ 
42 | Safitri, Permatasari. Analisis Dampak Pemekaran...

Tabel 4.2 Interval

\begin{tabular}{|c|c|}
\hline Interval & Kategori Jawaban \\
\hline $1-1,8$ & Sangat Kurang \\
\hline $1,9-2,7$ & Kurang \\
\hline $2,8-3,6$ & Cukup \\
\hline $3,7-4,5$ & Baik \\
\hline $4,6-5$ & Sangat Baik \\
\hline
\end{tabular}

Sumber : Kuisioner

Berdasarkan data yang telah diperoleh diatas dapat diketahui bahwa Indeks setelah pemekaran sebesar 4,04 dan dapat dikategorikan Baik kerena Intervalnya diantara $(3,7-4,5)$. Dari hasil indeks yang Baik ini dapat di analisis bahwa apa yang sudah menjadi tolak ukur dalam penelitian ini. Hal yang utama adalah bahwa setelah dilakukan pemekaran Provinsi (Kalimantan Timur) menjadi Provinsi (Kalimantan Utara) berdampak Baik terhadap Kesejahteraan Masyarakat.

\section{Kesimpulan dan Saran}

Pemekaran Provinsi (Kalimantan Timur) menjadi Provinsi (Kalimantan Utara) membawa dampak positif terhadap kesejahteraan masyarakat ini dilihat dari hasil penelitian yang menunjukan bahwa hasil nilai Indeks setelah pemekaran sebesar 4,04 dan dapat dikategorikan Baik kerena Intervalnya diantara $(3,7-4,5)$. Hasil yang Baik ini juga tidak terlepas dari upaya serius yang dilakukan pemerintah dalam meningkatkan kesejahteraan masyarakat diantaranya peningkatan pelayanan publik terhadap masyarakat. Upaya yang telah di lakukan pemerintah juga membawa hasil yang positif dengan meningkatnya IPM Kabupaten Bulungan di setiap tahun nya. IPM Kab Bulungan tahun 2018 telah meningkat sebesar 71,23 dibandingkan dengan tahun 2017 70,74 dengan laju pertumbuhan IPM sebesar 0,7 persen.

Secara keseluruhan bahwa pemerintah Provinsi Kalimantan utara terlah menjalankan hal-hal yang di sampaikan dalam PP No.129 Tahun 2000 Pasal 2 Tentang Pemekaran wilayah yang bertujuan untuk meningkatkan kesejahteraan masyarakat. Hal yang paling menonjol adalah pelayanan publik dengan upaya pemerintah yang memberikan bantuan ambulan gratis dan ambulan kepada masyarakat miskin. Pemerintah juga memberikan bantuan dengan dokter terbang untuk di seluruh kabupaten yang berada di provinsi kalimantan utara yang sulit terjangkau oleh pelayanan kesehatan, kemudian pemerintah 
memberikan JKN-KIS yang iuran setiap bulanya di bayarkan oleh pemerintah Provinsi dengan anggaran APBD.

Pemerintah juga memberikan bantuan pendidikan dengan Beasiswa Kaltara Cerdas untuk seluruh masyarakat di Provinsi Kalimantan Utara tanpa terkecuali. Pemerintah juga telah berencana untuk mendirikan MPP (Mal Pelayanan Publik) sehingga mempermudah masyarakat untuk cepat mendapatkan pelayanan selanjutnya pemerintah juga membuat aplikasi Lintang dan Siabang apalikasi ini guna memberikan informasi mengenai pelayanan. Pemerintah juga membangun infrastruktur jalan guna memperlancar kegiatan ekonomi masyarakat.

Berdasarkan hasil penelitian yang di lakukan maka, hal yang harus dilakukan pemerintah adalah tetap fokus dalam meningkatkan pelayanan publik kepada masyarakat baik itu di bidang kesehatan, pendidikan, pendapatan/pengeluaran, kemanan/ketertiban dan fokus untuk pengelolaan potensi daerah agar kedepanya masyarakat semakin sejahtera dan Provinsi Kalimantan Utara khususnya Kabupaten Bulungan dapat berkembang pesat dalam berbagai aspek yang dapat menunjang kesejahteraan masyarakatnya.

\section{DAFTAR PUSTAKA}

\section{Buku-Buku :}

Arikunto, S. (2006). Prosedur Penelitian. Rienika Cipta: Jakarta.

Sugiyono. 2014. Metode Penelitian Kuantitatif, Kualitatif, dan R\&D. Bandung : Alfabeta

Sugiyono, P. (2010). Dr. Metode Penelitian Pendidikan: Pendekatan Kuantitatif, Kualitatif dan R\&D Cet.

Sun'an, Muammil, Senuk, Ekonomi Pembangunan Daerah, (Jakarta: Mitra Wacana Media, 2015).

\section{Sumber Jurnal :}

Hidayat, S. Desentralisasi dan Otonomi Daerah dalam Perspektif State-Society Relation. [jurnal politik]. [Homepage on The Internet]. C2008

Kumorotomo, W. (2008). Desentralisasi fiskal: politik dan perubahan kebijakan, 1974-2004. Kencana Prenada Media Group.

Sari, M.E.P., \& Pratiwi, D.A. Faktor - Faktor yang Mempengaruhi Kesejahteraan Hidup Masyarakat Suku Laut Pulau Bertam Kota Batam. [jurnal trias politika]. [Homepage on The Internet]. C2018. 
44 | Safitri, Permatasari. Analisis Dampak Pemekaran...

Syah, N. Dampak Pemekaran Daerah Pada Pelayanan Publik Ditinjau Menurut Sistem Hukum Indonesia. Petita: Jurnal Kajian Ilmu Hukum dan Syariah, 3(2), 224-239. [ jurnal ilmiah]. [Homepage on The Internet]. C2018

Sumber Skripsi :

Hendrata, R. (2019). Dampak Pembentukan Daerah Otonomi Baru (DOB) Provinsi Kalimantan Utara Terhadap Stabilitas Perekonomian di Kabupaten Bulungan. Jurusan Program Ilmu Ekonomi Pembanguna Universitas Kaltara: Tanjung Selor

\section{Undang-undang :}

Undang-undang Nomor 32 Tahun 2004 Tentang Otonomi Daerah.

Undang-undang Nomor 32 Tahun 2014 Tentang Pemerintah Daerah.

Undang-undang Nomor 23 Tahun 2014 Tentang Pemerintah Daerah.

Undang-undang Nomor 20 Tahun 2012 Tentang Pembentukan Provinsi Kalimantan Utara.

Undang-undang Nomor 11 Tahun 2009 Tentang Kesejahteraan Sosial.

Peraturan Pemerintah Nomor 78 Tahun 2007 Tentang Cara Pembentukan, Penghapusan, dan Penggabungan Daerah.

Peraturan Pemerintah Nomor 129 Tahun 2000 Tentang Persyaratan Pembentukan dan Kreteria Pemekaran, Penghapusan dan Penggabungan Daerah.

\section{Website :}

http://disperindagkop.kaltaraprov.go.id/

https://www.bps.go.id/

https://bulungankab.bps.go.id/

https://kaltara.bps.go.id/

https://kbbi.web.id/ 